\title{
FEMINISMOS PARA ALÉM DOS FEMINISMOS: ÊTHOS CRÍTICO E TRANSFORMAÇÃO DO PENSAMENTO
}

\author{
GREGORY DA SILVA BALTHAZAR ${ }^{1 *}$ \\ ORCID: https://orcid.org/0000-0002-0371-1962 \\ FABIANA DE AMORIM MARCELLO2 ${ }^{2 *}$ \\ ORCID: https://orcid.org/0000-0001-9720-2650
}

RESUMO: Neste artigo, mais do que discutirmos os feminismos como uma forma de militância política, objetivamos problematizá-los como uma crítica radical às relações assujeitadoras que estabelecemos com as verdades de nosso tempo. Para tanto, discutimos duas obras do artista japonês Yasumasa Morimura, na medida em que encontramos pontos de ressonância entre essas imagens e alguns dos pressupostos do que chamamos êthos crítico feministas em sua capacidade de tensionar, de modo decisivo, aquilo que somos na ordem binária do gênero.

Palavras-chave: Feminismos; Gênero; Imagem.

\section{FEMINISMS BEYOND FEMINISMS: CRITICAL ETHOS AND THOUGHT TRANSFORMATION}

ABSTRACT: In this article, rather than discussing feminisms as a form of political activism, we aim to problematize them as a radical critic to the subjugation relationships we have established with the truths of our time. To this end, we discussed two works by the Japanese artist Yasumasa Morimura, insofar as we found resonance points between these images and some of the assumptions of what we call critical feminist ethos in its ability to tighten, in a decisive manner, what we are in the gender binary order.

Keywords: Feminisms; Gender; Image.

\footnotetext{
${ }^{1}$ Universidade Federal do Rio Grande do Sul, Núcleo de Estudos em Mídia, Educação e Subjetividade,Porto Alegre, RS, Brasil.

"Doutor em Educação pela Universidade Federal do Rio Grande do Sul. Membro do Núcleo de Estudos em Mídia, Educação e Subjetividade. E-mail:<gsbalthazar@gmail.com>.

${ }^{2}$ Universidade Federal do Rio Grande do Sul, Programa de Pós-Graduação em Educação,Porto Alegre, RS, Brasil.

"* Doutora em Educação pela Universidade Federal do Rio Grande do Sul. Realizou estudos de pós-doutorado no Institut d'Études Politiques de Paris. Professora do Programa de Pós-Graduação em Educação da Universidade Federal do Rio Grande do Sul. Bolsista PQ/CNPq. Membro do Núcleo de Estudos em Mídia, Educação e Subjetividade. E-mail: < famarcello@gmail.com >.
} 


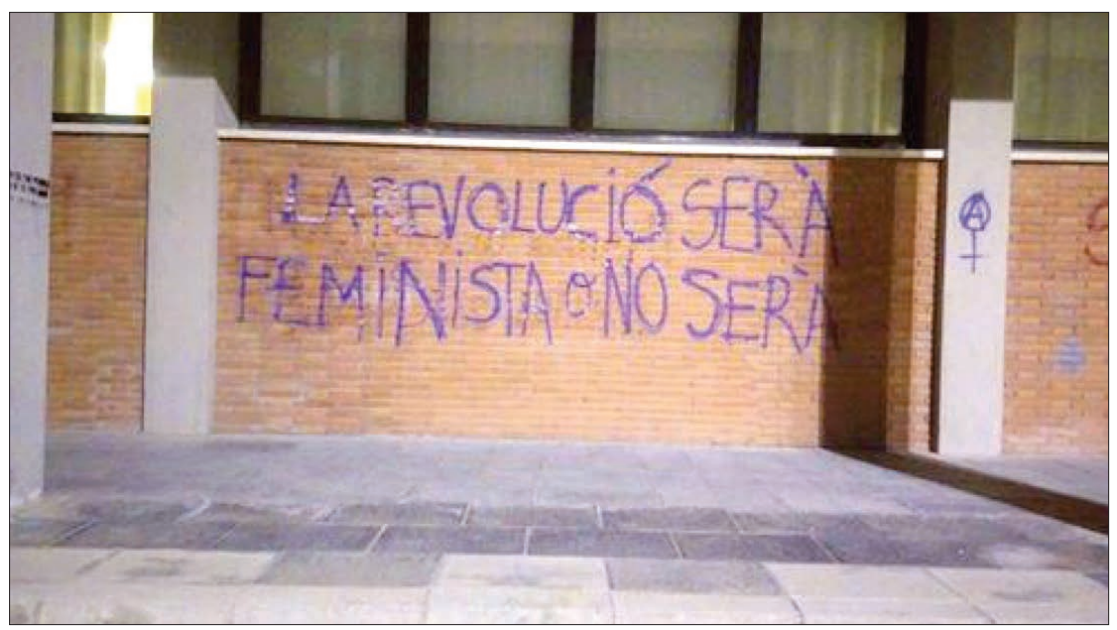

IMAGEM 1. Universidade de Barcelona - Espanha [detalhe].

Fonte: Raquel Leão Luz, abril, $2016{ }^{1}$

A revolução será feminista ou não será: essa é a frase que frequentemente ouvimos, nos dias de hoje, nas vozes de diferentes mulheres ou que lemos em paredes e muros em distintas cidades do mundo. Talvez possamos dizer que, de algum modo, ela expressa também uma espécie de renascimento ou, pelo menos, uma espécie de fortalecimento dos feminismos como um movimento social em nível internacional. $\mathrm{Na}$ atual conjuntura, os feminismos se colocam como vanguarda na luta contra os fascismos micro e, sobretudo, macropolíticos consolidados na emergência de governos ultraliberais em vários países da Europa e das Américas. Lembramos, por exemplo, em nosso país, como diferentes meios de comunicação se referiram à primavera das mulheres ${ }^{2}$ ou à primavera feminista como ponto de eclosão das novas lutas feministas em direção à construção de um protagonismo singular quanto à manutenção e conquista de direitos de diferentes ordens.

Não é nosso objetivo neste texto nos debruçarmos sobre a inegável importância política da (re)consolidação contemporânea dos feminismos; interessa-nos, antes, pensar em uma dimensão específica desses movimentos e de seus desdobramentos na edificação do que chamamos de um êthos crítico feminista: os modos de subjetivação promulgados pelos feminismos. Mais precisamente, interessa-nos problematizar os feminismos em sua preocupação em criar um êthos crítico comprometido com a criação de novos espaços sociais e outras condições subjetivas para as mulheres, bem como novas e múltiplas experiências de gênero e mesmo sexuais. 
Neste sentido, de início, propomos que afirmar um êthos crítico feminista reside na possibilidade de pensar os feminismos como uma atitude crítica - usando o sentido proposto por Judith Butler $(2005$; 2009; 2017) a partir de uma palestra proferida, em 1978, por Michel Foucault $(1997)^{3}$ - , entendida como a arte de não ser governado totalmente (no caso desta discussão, por uma cultura política de gênero sexista e heteronormativa). Em função disso, e mais precisamente, interessa-nos pensar nos modos como os feminismos lançam à cultura uma crítica radical às formas como nos tornamos sujeitos das verdades hegemônicas de nosso tempo, bem como, em contrapartida, investem na criação de outras formas de nos constituirmos como sujeitos de gênero e sexualidade.

Assim, o objetivo deste artigo é compreender os feminismos não exclusivamente como um movimento social; para além dessa marca decisiva e fundamental, buscamos problematizar os feminismos como uma prática filosófica, ou seja, como um "trabalho crítico do pensamento sobre o próprio pensamento", uma espécie de exercício capaz de nos mobilizar a "pensar diferentemente do que se pensa" (FOUCAULT, 1984, p. 13). No seio desse debate, elegemos como campo de discussão as artes visuais - mais propriamente, a análise de duas obras do artista japonês Yasumasa Morimura -, na crença de que haveria pontos de encontro, de ressonância, entre alguns elementos erigidos pela crítica feminista e as obras do artista. Ao fazer isso, nosso pressuposto é o de que, se podemos dizer que os movimentos feministas estão inegavelmente ligados a um tipo particular de crítica do presente, isso nos permite entender que eles, ao mesmo tempo, também excedem seu caráter mais imediato - a militância política - em direção a um êthos que poderíamos qualificar como feminista e que pode ser visível em outros espaços da cultura (sendo, por certo, a arte apenas um deles). As imagens de Morimura serão, portanto, problematizadas como uma espécie de caminho possível para, digamos, mostrar a dinâmica desse êthos crítico feminista.

Cabe ressaltar, de imediato, que não desconsideramos o fato de que feminismos não supõem, de modo algum, um conceito homogêneo. Com efeito, e tal como proposto por Chantal Mouffe (1999, p. 47), não buscamos sugerir um feminismo mais verdadeiro-o que, necessariamente, seria apontar uma forma mais correta de política feminista -, uma vez que a ideia mesma de feminismo está sujeita a diferentes posturas políticas e teóricas possíveis. Como afirma a autora, "as metas feministas podem ser construídas de maneiras muito diferentes, de acordo com a multiplicidade dos discursos nos quais possam estar inseridas: 
marxista, liberal, conservador, separatista radical, democrático radical, entre outros" (Ibidem). No sentido de propor a ideia de êthos crítico feminista, e ainda seguindo as proposições de Mouffe, nossa aposta reside na compreensão dos feminismos não como uma política tecida por "mulheres como mulheres", mas, antes, como uma forma mais ampla de articulações políticas, ou seja, "como uma luta contra as múltiplas formas que a categoria mulher é construída como subordinação" e, mais amplamente, como conjunto de práticas comprometidas em ressignificar e multiplicar radicalmente seus significados.

Além disso, merece ser dito que, se trazemos para este texto uma dimensão analítica sobre algumas obras de arte, isso se deve ao modo como entendemos que a discussão mais ampla aqui colocada se inscreve, decisivamente, no campo da educação. De modo mas preciso, afirmamos que, inspirados em Rosa Fischer (2009), problematizar o lugar das imagens nos modos como hoje nos constituímos como sujeitos se relaciona, invariavelmente, a uma educação ética do olharo que exige considerar, nos termos de uma filosofia da imagem, a experiência do olhar como fundamental para a construção de uma educação que privilegia possíveis resistências às redes de saber-poder contemporâneas. Ou seja, realizar o presente debate tomando como base uma analítica da imagem indica uma aposta sobre os modos pelos quais o conceito mesmo de educação se vê ampliado - nesse caso, falar em uma educação ética do olhar é, como propôs Rosa Fischer (Ibidem), sugerir a urgência de se problematizar a permeabilidade entre a arte, a filosofia e a vida; no sentido de sugerir como as imagens artísticas (mas, certamente, não só) possuem a potência de nos convocar a questionar os modos como somos ensinados a sermos sujeitos das verdades de nosso tempo e, ao mesmo tempo, sugerir, igualmente, "condições e possibilidades infinitas, imprevisíveis e indefinidas de nos transformarmos e de sermos diferentes do que somos" (Ibidem, p. 94).

Para dar conta destas discussões, estruturamos o presente artigo em duas seções: a primeira delas diz respeito ao debate sobre os modos como somos constituídos como sujeitos das normas e, frente a isso, sobre as possibilidades de uma atitude crítica por meio da qual podemos tecer outras relações com essas verdades em direção a outras possibilidades subjetivas. Nessa primeira seção, então, nosso interesse é traçar uma aproximação entre os feminismos e a ideia de crítica foucaultiana, permitindo-nos argumentar sobre a edificação do que chamamos de um êthos crítico feminista, concebido como uma maneira de ser e de se conduzir, enfim, como um modo de ser sujeito afastado dos modos de sujeição marcadamente falocêntricos. 
A segunda seção refere-se, mais propriamente, à análise de dois autorretratos de Yasumasa Morimura, na tentativa de mostrar como eles operam, em alguma medida, com um tensionamento na ordem discursiva binária do gênero. As imagens serão trabalhadas em sua possibilidade de nos convocar, acreditamos, a uma atitude crítica quanto à relação que estabelecemos com as verdades hegemônicas que circulam em nossa cultura - no caso do gênero, regimes discursivos binários caros tanto aos discursos de dominação como aos de resistência -, abrindo-nos à possibilidade de reinscrevê-las na ordem da criação e da transformação.

\section{POR UM ÊTHOS CRÍTICO FEMINISTA}

"Como ocorre que o sujeito humano se torne ele próprio um objeto de saber possível; através de que formas de racionalidade, de que condições históricas e, finalmente, a que preço?", questionou Michel Foucault (2013a, p. 334, grifos nossos) em uma entrevista concedida ao filósofo Gérard Raulet, publicada em 1983, na revista Telos. Iniciar esta seção por meio do questionamento de Foucault - por uma pergunta que é, antes de tudo, genealógica sobre os modos como as verdades determinam, em maior ou menor grau, o que somos e o que podemos ser em um determinado contexto -, nos permite trazer uma questão cada vez mais urgente e necessária: a necessidade de assumirmos uma postura problematizadora diante dos modos como nos constituímos como sujeitos inscritos nas políticas da verdade de gênero e sexualidade, sobretudo em suas dimensões ontológicas e epistemológicas.

No tocante ao campo epistemológico, Foucault (2010a) evidenciou como, a partir da modernidade, a relação do sujeito com a verdade se efetiva, muito singularmente, intermediada pela razão e pelo conhecimento. Para o autor, é a partir deles [razão e conhecimento] e de sua complementaridade irrenunciável que as condições de acesso do sujeito à verdade podem ser definidas. Foucault (2014, p. 185) destaca, a partir de Nietzsche, que, de fato, somos até hoje herdeiros dessa inextricável relação a partir da qual o que entendemos como conhecimento (na qualidade de produção de um sujeito cognoscente) se torna sinônimo de verdade.

Qual a importância disso para as questões aqui discutidas? Ora, é no jogo do verdadeiro e do falso, em que o conhecimento ocupa lugar ímpar para a consolidação de um dado saber como verdade, que a dimensão ontológica da política da verdade emerge e atua na produção de sujeitos. Afirmar sobre o modo como a verdade 
atua ontologicamente implica entender o quanto ela se faz próxima, nos mínimos gestos, daquilo que somos (ou devemos ser) enquanto sujeitos. Entendida como forma também de poder, a verdade "aplicase à vida cotidiana imediata que categoriza o indivíduo, marca-o com sua própria individualidade, liga-o à sua própria identidade, impõelhe uma lei de verdade que devemos reconhecer e que os outros têm de reconhecer nele" (FOUCAULT, 2010a, p. 278).

Como desdobramento desta ideia, pensamos, de modo mais preciso, sobre a relação entre verdade e as formas de viver o gênero e a sexualidade a partir das contribuições de Judith Butler. Logo, entendemos que a verdade pode, no sentido da sujeição, estabelecer relações de reconhecibilidade em que os marcos normativos de uma ontologia do sujeito, instituídos pelas redes de saber-poder, determinam o que é permitido ao indivíduo:

Em Foucault, parece, há um preço por se dizer a verdade sobre si mesmo, precisamente porque o que constitui a verdade será enquadrado por normas e modos específicos de racionalidade que emergem historicamente e são, nesse sentido, contingentes. Na medida em que dizemos a verdade, conformamo-nos a um critério de verdade e aceitamos esse critério como o que nos vincula a nós mesmos. [...] Portanto, dizer a verdade sobre si mesmo vem com um preço e o preço é a suspensão de uma relação crítica com o regime de verdade em que se vive (BUTLER, 2005, p. 121-122, grifos nossos).

O que a autora nos indica, baseada em Foucault, é que não somos meros efeitos dos regimes de verdade; antes disso, os atos de verdade a que somos convocados em nossa cultura nos constituem (e, de modo paralelo, são por nós constituídos) a certo preço como sujeitos, e isso de modo historicamente contingente. Quando a autora afirma que esse preço implica a suspensão de uma relação crítica com um regime de verdade, ela mostra o quanto a adesão a ele implica uma negação de sua historicidade. Ou seja, Judith Butler destaca que a edificação de certo conhecimento tido como a verdade pressupõe, em algum sentido, exorcizá-lo de sua historicidade, pressupondo-o como ahistórico.

Como, então, se efetiva a resistência a um tipo de poder que não exige somente a obediência, mas que nos convoca a atos de verdade que correspondem à manifestação constante daquilo que se é - no caso da discussão deste texto, a atos de verdades que dizem de nosso sexo, de nosso gênero e de nossos desejos? É, pois, no conceito de crítica foucaultiano que encontramos uma possibilidade de pensar em formas de resistência aos modos de sujeição às verdades. A crítica, concebida como uma atitude diante do mundo, nos coloca diante de uma questão tão direta como complexa: como não ser governado pelas verdades hegemônicas de nosso tempo? 
Para Foucault, enquanto atividade questionadora dos modos como somos governados por certas verdades, a crítica diz respeito a uma atitude diante do mundo, um modo de transformação e mesmo de criação do pensamento:

Faz̧er a crítica é tornar difícil os gestos mais simples. Nessas condições, a crítica (e a crítica radical) é absolutamente indispensável para a transformação, pois uma transformação que ficasse no mesmo modo de pensamento, uma transformação que só fosse uma certa maneira de melhor ajustar o mesmo pensamento à realidade das coisas, não passaria de uma transformação superficial. Em compensação, a partir do momento que começamos a não mais poder pensar nas coisas como nelas pensamos, a transformação torna-se, ao mesmo tempo, muito urgente, muito difícil e absolutamente possivel (FOUCAULT, 2013b, p. 356-357, grifos nossos).

A crítica é, pois, uma forma de colocar em movimento uma transformação do pensamento, como um trabalho de constante questionamento do que somos e do que podemos ser. De algum modo, a crítica diz do ato de fraturar as verdades das quais somos sujeitos. Portanto, ela é um exercício que pode deslocar o pensamento da ordem da sujeição, inscrevendo-o, mesmo que de forma provisória, como possibilidade de resistência, de luta às formas instituídas pelas quais nos fazemos sujeitos em nossa cultura. Como, então, problematizar os feminismos como atitude crítica - ou seja, como essa forma de pensamento que interroga a viabilidade e aceitabilidade do jogo do verdadeiro e do falso?

Em uma das poucas passagens que faz referência aos feminismos, precisamente sobre o movimento lésbico, Foucault afirma:

Eu diria, também, que, no que concerne ao movimento lésbico, o fato, em minha opinião, de que as mulheres foram, durante séculos e séculos, isoladas na sociedade, frustradas, desprezadas de muitas maneiras lhes deu uma verdadeira possibilidade de construir uma sociedade, de criar certo tipo de relação social entre si, fora de um mundo dominado pelos homens (2014b, p. 258).

Trazemos estas considerações justamente porque, em seu conjunto, elas sugerem que os feminismos, sobretudo em suas vertentes mais dissidentes, operaram um movimento crítico radical às possibilidades subjetivas promulgadas por uma cultura política de gênero marcadamente falocêntrica e heteronormativa. A partir da ideia de que o movimento lésbico pôde criar, nos anos 1970 , comunidades e formas de sociabilidades distantes das normas androcêntricas, compreendemos que a crítica dos feminismos esteve (e está) alicerçada, de modo bastante plural, ao que podemos chamar de filoginia da cultura. Isto é, um movimento cultural de feminização no qual a sociedade passa a romper com regimes de verdades binários 
marcados por modos coercitivos de atuação do gênero, em nome de valores mais femininos e feministas, especialmente aqueles vinculados à solidariedade e à liberdade (RAGO, 2001).

É sabido que a crítica filógina empreendida pelos feminismos, em suas múltiplas vertentes, estimulou a emergência de outras possibilidades subjetivas para as mulheres (ainda que não somente isso), uma vez que hoje elas possuem outro tipo de acesso ao mundo público (como a participação no mercado de trabalho e a inserção nos diversos níveis de educação). Além disso, as mulheres, na atualidade, vivenciam relações de gênero, de certo modo, mais diluídas e menos hierárquicas, mantendo relações mais libertárias com os corpos, com o sexo, com os outros e consigo mesmas (RAGO, 2004).

Sob este prisma mais amplo da crítica feminista, há, portanto, um pressuposto específico que buscamos defender a partir das proposições pós-estruturalistas: aquele que incide na compreensão dos feminismos para além da militância política, passando a assumilos como um modo de ver e conceber o mundo, como possibilidade mesma de transformação e de criação do pensamento. Indagar os feminismos sob a ótica da crítica foucaultiana é, portanto, uma aposta na potência desestabilizadora das práticas feministas, pois, como crítica, os feminismos colocam em xeque as verdades naturalizadas sobre o gênero e a sexualidade. Se a crítica é uma espécie de "um instrumento, um meio para um futuro ou para uma verdade que ainda não se conhece ou que ainda não existe" (FOUCAULT, 1997, p. 42), os feminismos se constituem como um ato de inservidão aos modos de sujeição de gênero e sexualidade contemporâneos, colocando em movimento a possibilidade de nos constituirmos como sujeitos de maneira distante daquilo que nos sugerem os marcos estabelecidos pelos regimes de verdade e, mais do que isso, de nos constituirmos como sujeitos de maneira irredutível às políticas de reconhecimento sugeridas por esses mesmos marcos.

Obviamente que não afirmamos que os feminismos desfizeram todas as desigualdades de gênero existentes ou que as mulheres não sofreram (e sofrem) de diferentes formas com o falocentrismo de nossa sociedade, muito menos negamos que existam entraves políticos no pensamento feminista. Antes disso, na esteira Judith Butler (2008), destacamos a inextricável relação dos feminismos com seu objeto de crítica, isto é, o fato de que a resistência não é externa às redes de saberpoder que busca questionar, mas, ao contrário, é delas parte inseparável.

Em uma análise sobre a noção de poder no pensamento feminista pós-estruturalista, Saba Mahmood (2005) demonstrou 
como Judith Butler localizou, a partir Foucault, que a estabilidade das normas das quais somos sujeitos depende de contínuos processos de reiteração e, de modo paralelo (ainda que aparentemente paradoxal), que as possibilidades de resistência são, por sua vez, inseparáveis das normas. Para a autora paquistanesa, as proposições lançadas por Judith Butler acabam, em algum nível, "operando as resistências em contextos onde as normas são colocadas em questão ou são sujeitas a ressignificações" (Ibidem, p. 21), legando, muitas vezes, as possibilidades de crítica a uma lógica binária de normalização/ subversão, reiteração/ressignificação. Na crítica que Mahmood faz do próprio conceito de crítica de Butler - e no sentido de defender a expansão do termo -, a autora mostra, ao analisar o movimento feminino pietista muçulmano, como as mulheres muçulmanas puderam tecer formas de viver que não configuram, necessariamente, em uma resistência na qualidade de subversão da norma: em gestos mínimos - gestos que, por certo, poderiam ser tomados de outra perspectiva como de viés conservador -, aquelas mulheres afirmam modos de vida e de ação do centro mesmo da normatividade. ${ }^{4}$

Se trazemos tais considerações é pelos desdobramentos que elas sugerem sobre o conceito mesmo de crítica, tal como discutido por Mahmood:

A crítica, desse ponto de vista [da resistência], tem a ver com a desconstrução bem-sucedida da posição do oponente à exposição da implausibilidade do seu argumento e da inconsistência da sua lógica. Este é um entendimento limitado da noção de crítica. A crítica, penso, é mais poderosa quando deixamos em aberto a possibilidade de nós mesmos sermos mudados pelo envolvimento com a visão de mundo dos outros e de podermos apreender coisas que desconhecíamos antes de seu envolvimento (2005, p. 36).

Nesse sentido, a autora nos convoca a ampliar o conceito de crítica proposto por Foucault e que, recentemente, foi assumido por Judith Butler. Nos termos de um êthos crítico feminista, a abertura ao outro - mesmo que seja um oponente a ser enfrentado - coloca em questão como, apesar de sua multiplicidade, os feminismos assumiram, quase que de modo intransponível, a resistência tecida pelas mulheres como uma atitude crítica - no sentido da subversão, da fratura, da quebra - das relações de dominação das redes de saber-poder: "o feminismo, portanto, oferece um diagnóstico do estatuto das mulheres nas diversas culturas e uma diretiva [universalizante e essencialista, acrescentamos] para a mudança da situação das mulheres" (Ibidem, p. 10).

Com base nessas discussões, insistimos que, ao propormos a ideia de um êthos crítico feminista, buscamos justamente problematizar 
as pretensões universalizantes sobre o sujeito e a resistência de um feminismo marcadamente liberal e eurocêntrico, no sentido de levarmos em consideração - tal como as discussões de Mahmood (2005) nos permitem - que a crítica não é sinônimo de resistência às normas, mas pode ser também "a capacidade de ação criada e possibilitada por relações de dominação específicas” (Ibidem, p. 18).

Falar, portanto, em um êthos crítico feminista significa, neste texto, poder discutir os feminismos em seu caráter discursivo e tensionador de práticas culturais, políticas, sociais e econômicas. Mais precisamente, trata-se de pensar nas potencialidades de se fazer sujeito de um êthos crítico feminista a partir de uma compreensão específica do conceito de gênero: não aquele que diz exclusivamente das relações de homens e mulheres - e dos feminismos como sinônimo de uma militância de e para mulheres -, mas, tal como propõe Dagmar Meyer (2003), aquele que assume o gênero em sua interface com o campo da educação, qual seja: como um organizador da cultura e do pensamento, o que nos permite, então, sugerir problematizar os feminismos como um modo de pensar $o$ e de se estar no mundo.

Tal como discutimos, problematizar o êthos crítico feminista sugere pensar como as normas podem não somente serem subvertidas, mas, paradoxalmente, incorporadas para afirmar outros modos de vida. Mais centralmente, nossa aposta reside em problematizar como o êthos crítico feminista nos convocam a questionarmos os modos como vivemos e pensamos o gênero - nomeadamente, como iremos explorar na seção seguinte, dos modos de sujeição das mulheres, pensadas, sobretudo, sob a ótica de um sujeito dos feminismos. Em vista disso, consideramos como intransponível, em nossa análise, a intersecção do gênero com outros marcadores sociais, tal como reivindicada, nos anos 1970, pelas feministas negras, lésbicas e operárias: uma prática feminista interseccional que leve em consideração a diferença dentro da diferença (BUTLER, 2015; hooks, 2013).

Se falamos em um feminismo interseccional, não é, certamente, no sentido de uma defesa de formas de encontros de identidades tomadas, muitas vezes, como essência do que somos ou do que podemos ser - uma abordagem que, como demonstrou Butler (2008), coloca a crítica feminista nos mesmos termos das normas que buscam questionar. Antes disso, a interseccionalidade é tomada aqui como uma possibilidade de dar a ver como o êthos crítico feminista borra justamente as noções identitárias tão caras aos movimentos sociais, possibilitando-nos, em uma perspectiva pósestruturalista dos feminismos, conceber uma crítica que sustenta a 
potência da pós-identidade como um caminho possível para uma forma de pensamento, de uma atitude política, dissidente das formas instituídas de ser sujeito (BUTLER, 1998; 2009). Com efeito, e articulando tais questões às proposições de Saba Mahmood (2005) trazidas anteriormente, apostamos na crítica dinâmica inseparável do encontro mesmo com o outro, com uma diferença que mobiliza a uma transformação daquilo que somos.

Assim, perguntamos: que outras formas de ser sujeito são sugeridas por um êthos crítico feminista, entendido como espaço de pensamento e criação que excede os movimentos feministas stricto sensu? Para dar conta dessa questão, tomamos como tema de análise as artes visuais - mais especificamente, duas obras de Yasumasa Morimura -, visando, assim, sugerir algumas respostas possíveis a essa indagação. A escolha pelas artes visuais, e pela arte de Morimura de modo particular, se encontra, como propôs Foucault (2010b), na compreensão da arte não como algo relacionado apenas a um objeto - seja ele uma pintura, uma escultura, uma fotografia -, mas como potência de fazer da própria vida uma obra passível de criação. Assim, as imagens de Morimura foram aqui selecionadas por se efetivarem como um lugar de multiplicação e de intensificação dos feminismos na qualidade de uma prática filosófica, um trabalho sobre o pensamento, que nos convoca a problematizarmos nossas subjetividades de maneira radical.

\section{ENTRE O OCEANO E A MONTANHA: A ARTE DE YASUMAMA MORIMURA}

Beleza é algo que incita uma comoção. É como a praia. Quando a água atinge a costa, você vê uma comoção e eu considero isso belo. No Japão, nós temos uma frase para descrever algo estranho e difícil de definir: "há coisas que você não consegue determinar se pertencem ao oceano ou à montanha". Este sou eu (MORIMURA, 2006, s.p., grifos nossos).

O excerto acima é extraído de uma entrevista concedida por Yasumasa Morimura, em 2006, à jornalista e crítica de arte Kay Ioti e foi publicada no The Japan Times, por ocasião da exposição Season's of Passion/A Requiem: Chapter 1 na Shugo Arts Gallery, em Tóquio. Nela, lemos a resposta dada pelo artista ao ser interpelado pela seguinte questão:

[...] seu público considera sua obra bela e divertida, mas, ao mesmo tempo, a ambiguidade sexual às vezes cria confusão e inquietação. Você se considera, em alguma parte de sua mente, uma mulher? Ou você deseja ter sido uma mulher? Ou você é gay? Ou você está apenas tentando confundir o seu público? (MORIMURA, 2006, s.p.). 
A pergunta da jornalista não é gratuita; ao fazê-la, ela busca colocar em cena pressupostos frequentemente sustentados por uma relação, por certo, sintomática da forma como nos fazemos sujeitos das verdades de nosso tempo: o gênero denotaria uma unidade ontológica marcadamente binária, em que um corpo concebido como naturalmente sexuado (masculino ou feminino) seria presumido a partir de um gênero (nossa performance como homens ou mulheres) e este, consecutivamente, teria por efeito a constituição de uma forma específica de desejo - a heterossexualidade (BUTLER, 2008). Do modo como ali situada a questão de Kay Ioti, talvez provocativamente, Morimura estava sendo interpelado a dizer $a$ verdade de si que vela, como mostrou Foucault, no fundo do sexo: $:^{5}$ afinal, o que ele é, efetivamente, na ordem binária das coisas?

Para nós - e aqui reside nossa justificativa para a escolha da obra do artista japonês -, o que nos causa comoção na obra de Morimura reside justamente na indeterminação aludida pelo espaço infinito que se localiza entre o oceano e a montanha, concebido como um ato de resistência à redução de sua arte - e, de algum modo, de sua própria existência - às políticas da verdade que nos interpelam a todo tempo a dizer de nós mesmos dentro de determinados limites. Se somos assujeitados a uma heterossexualidade compulsória em sua interface inseparável com o gênero enquanto estrutura binária de pensamento, a obra de Morimura pode sugerir - e é nisso que apostamos - a possibilidade de nos fazermos sujeitos de modo afastado de uma estrutura polarizada de inscrição. Logo, problematizaremos dois autorretratos de Morimura, produzidos entre o final da década de 1980 e a década de 1990, por entender que, cada um a seu modo, nos convidam não somente a tensionar os marcos normativos de uma cultura política de gênero sexista e heteronormativa, mas, também, e de modo paralelo, encontram ressonância com as formas como os feminismos operam resistências à lógica binária dos discursos normativos que buscam questionar. Se usamos o termo ressonância é para indicar que não assumimos as obras do artista como feministas, nem mesmo inscrevemos suas imagens sob o crivo de uma arte feminista. Valemo-nos da ideia de uma ressonância, na medida em que encontramos ali uma espécie de intensificação de uma dimensão muito específica dos feminismos, qual seja, aquela relacionada ao fato de eles se constituírem como um trabalho crítico sobre (e de transformação) do pensamento. Mais centralmente, apostamos, nos termos das proposições de Saba 
Mahmood (2005), que as imagens de Morimura fazem reverberar a crítica da diferença dentro da diferença lançada em 1970 e retomada hoje por correntes feministas que não se sentem incluídas na ideia mesmo de sujeito dos feminismos. Em outros termos, e como tentaremos demonstrar, as imagens que trazemos para o debate tensionam, em sua articulação com a crítica feminista, não somente a ordem binária das normas de gênero e sexualidade, mas, também, uma noção universalizante de sujeito cara aos feminismos liberais. Assim posto, a ideia de um feminismo interseccional, talvez, apareça como uma forma de questionar o próprio ideal identitário da militância feminista, sugerindo, com isso, uma prática feminista crítica que desloca nosso olhar na relação que tecemos com a alteridade.

Dito isto, as questões que nos mobilizam nesta seção são: como pensarmos a obra de Morimura em sua potência de nos sugerir um êthos crítico feminista? A que sujeito esse êthos dá lugar? Com o intuito de debatermos essas perguntas, acreditamos que, longe dos consensos identitários, as imagens selecionadas concentram a potência de nos provocar a nos reinscrevermos no jogo do verdadeiro e do falso no diálogo com um feminismo dissidente. Assim, apostamos que o êthos crítico feminista encontra na arte de Morimura um espaço fértil de diálogo, convidando-nos a partilhar de sua crítica e, assim, inscrever nosso pensamento como força afirmativa.

Inicialmente, é preciso considerar que a arte de Yasumasa Morimura foi profundamente marcada pelas experiências que o artista teve ao crescer em um Japão pós-guerra, vivendo uma verdadeira profusão cultural com a inserção da cultura ocidental no país. Desde os seus primeiros autorretratos nos anos 1980, é visível em suas obras o contato (e tensionamento) entre a cultura ocidental e oriental, sendo esse o aspecto mobilizador para a proposição de algumas respostas possíveis às questões que aqui lançamos. A primeira série de autorretratos de Morimura, intitulada Danghter of Art History (produzida a partir de 1985 e que reaparece em produções atuais do artista), emergiu com um tom irônico frente à própria noção de arte que passava a adentrar a cultura japonesa - e isso a partir de uma intensa experimentação artística que, por meio da releitura de pinturas canônicas da arte ocidental cujo tema central era o feminino, levou ao campo da experiência estética um sentido de dissenso com a hegemonia das artes ocidentais e com os modos como elas instituem gênero. 


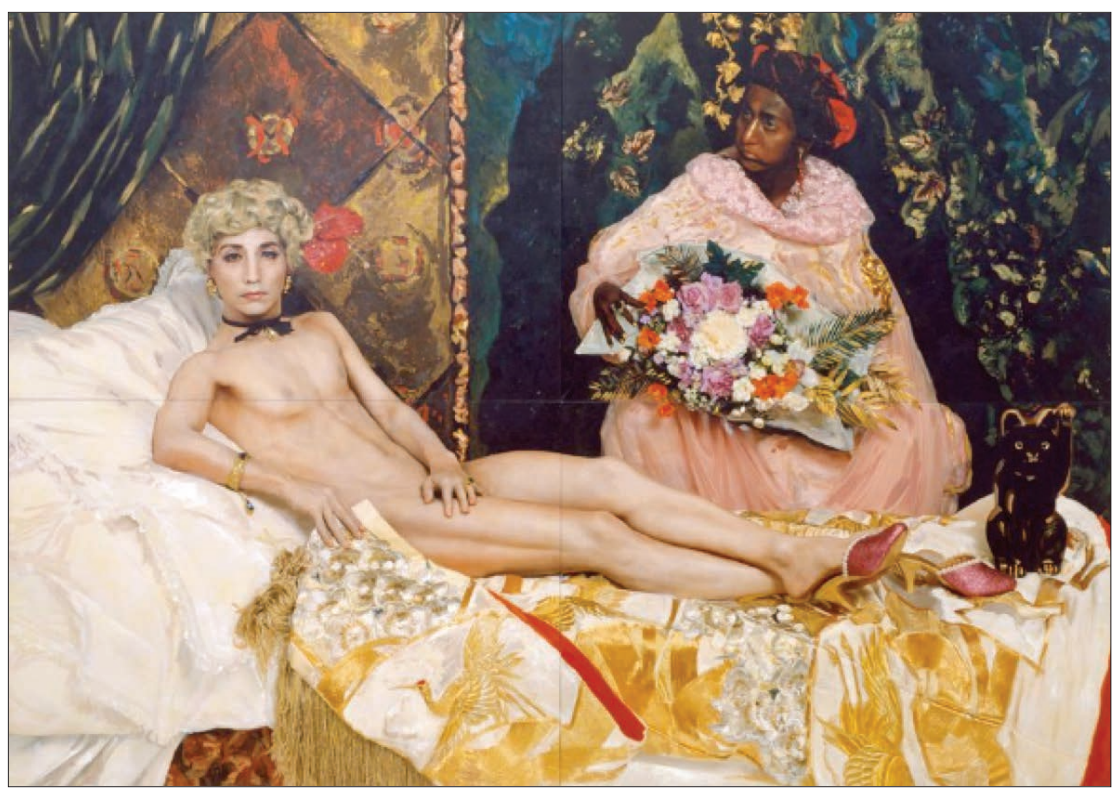

IMAGEM 2. Portrait (Futago) de Yasumasa Morimura (1988).

C-print com tinta acrílica e gel médium, $210.19 \times 299.72 \mathrm{~cm}$

San Francisco Museum of Modern Art, San Francisco - Estados Unidos

Fonte: https://www.sfmoma.org/artwork/97.788\#full-caption

Dos mais de 300 autorretratos que compõem a obra de Morimura, um dos mais conhecidos é Portrait (Fugato) (Imagem 2), produzido em 1988 como parte da série Daughter of Art History. Nele, o artista se apropriou e recriou a canônica pintura Olympia (Imagem 3) de Édouard Manet, produzida em 1863 e exposta pela primeira vez no Salão de Paris de 1865. Em uma primeira aproximação, o título da fotografia de Morimura, conforme David Kahn (2007, p. 10), nos dá algumas pistas dos sentidos da apropriação da obra de Manet. Em uma tradução livre, a palavra futago pode ser traduzida como gêmeos, o que, segundo o autor, refere-se ao sentido dúbio da apropriação empregada por Morimura: de um lado, em função de a imagem (de Morimura) ser uma releitura de outra (de Manet); de outro, pela dupla representação do artista na imagem - como a prostituta e como a serva (Ibidem). Cento e vinte e cinco anos separam o momento de criação das duas imagens. Futago e Olympia formam, de algum modo, um diálogo anacrônico de uma imagem do feminino, cuja sobrevivência, no ato mesmo de apropriação, de ressignificação, de releitura imagética, reinscreve o lugar do corpo feminino. 


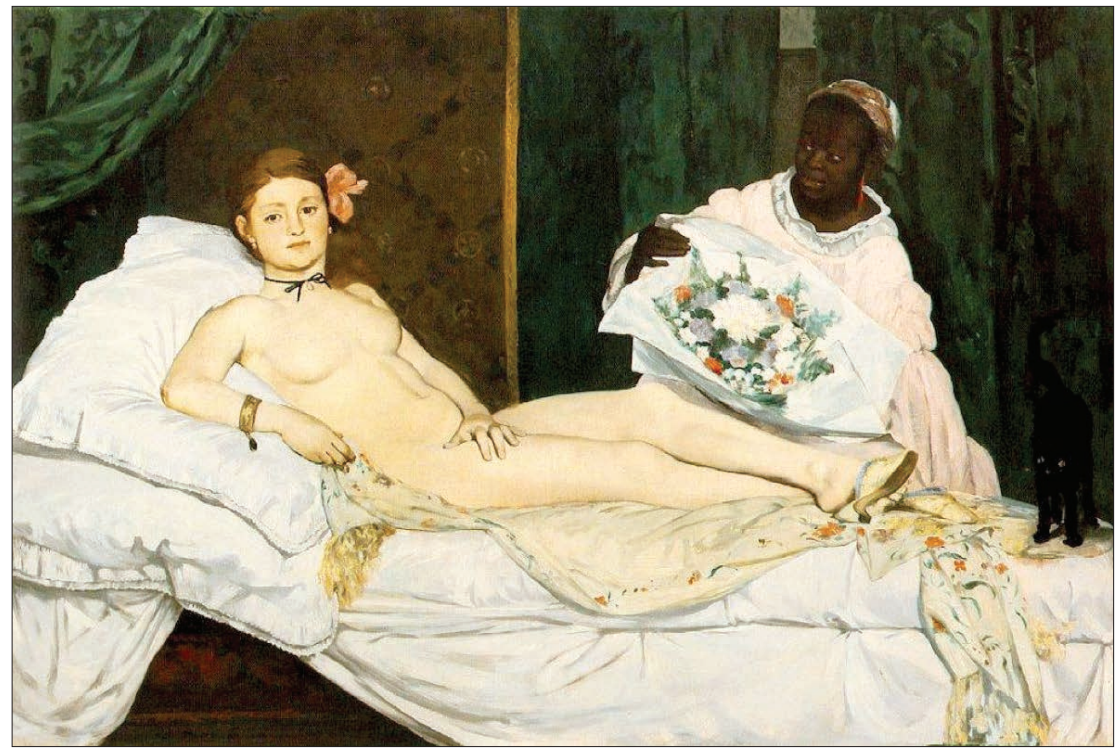

IMAGEM 3. Olympia de Édouard Manet (1863)

Óleo sobre tela, $130.5 \mathrm{~cm} \times 190 \mathrm{~cm}$

Musée d'Orsay, Paris - França

Fonte: http://www.musee-orsay.fr/en/collections/index-of-works/notice.html?no cache = $1 \&$ nnumid $=712 \& \mathrm{cHash}=$ b6ec345dc6

Para muitos, a arte de Manet - e a pintura Olympia, de modo especial - expressa uma ruptura como as normas do sistema de arte acadêmico e, por isso mesmo, uma forma de pensar a sociedade. $\mathrm{O}$ escândalo causado por Olympia, no Salão de 1865, teria sido, em alguma medida, emblemático das formas como a estética empreendida por Manet tensionava uma questão de classe, como colocou T. J. Clarck (2004, p. 208), em seu livro sobre a obra de Manet e a modernidade: "o signo de classe na Olympia era a nude". De modo mais preciso, na contramão das representações acadêmicas idealizadas da prostituição, Olympia dava a ver a classe inerente ao corpo da cortesã, pois a forma como o seu corpo foi idealizado por Manet colocou a burguesia oitocentista diante da nudez de Victorine Meurent (uma cortesã da classe trabalhadora) e conectou seu corpo a algumas características da cultura erudita da época (Ibidem).

É preciso considerar, no entanto, que, para a historiadora Griselda Pollock (2003), Clarck realizou uma análise que sobrevalorizou a classe em detrimento de outros marcadores sociais, como é o caso do gênero. Logo, se Olympia criticou, com o corpo da prostituta, a estrutura de classe na arte, retificou, ao mesmo tempo, o lugar que a arte acadêmica reservava ao corpo feminino: um 
objeto a ser possuído, esmiuçado e desejado pelo olhar masculino. Trazemos essas considerações, pois, da sobrevivência de um corpo pela apropriação, Morimura faz um novo deslocamento que se conjuga àquele empreendido por Manet, lançando-se a problematizar algo que, antes, havia sido apagado: o corpo de Olympia e o de sua serva, Laura, são substituídos pelo corpo do artista japonês, em um encontro inegável dos vetores de gênero àqueles de raça, tão caros aos discursos das diferenças humanos oitocentistas.

Alinhado, então, às questões de raça e, mais centralmente, de gênero, as imagens de Morimura colocam em tensionamento o modo como esses marcadores sustentam a visão do Ocidente sobre o Oriente. Aqui reside uma aproximação da arte de Morimura aos feminismos, uma vez que Futago dá a ver como o gênero, no encontro com outros vetores (como a raça), estrutura, inclusive até hoje, o orientalismo, bem como as formas como a intersecção de tais redes de saber-poder nos constituem como sujeitos.

Conforme proposto por Edward Said (2007, p. 33), o orientalismo se constitui como um discurso pelo qual a Europa "foi capaz de manejar e até produzir o Oriente política, sociológica, militar, ideológica, científica e imaginativamente". Em outros termos, o orientalismo é pensado como uma forma binária de pensamento, pautada em uma distinção ontológica e epistemológica entre Ocidente e Oriente. As artes visuais e literatura desempenharam, sobretudo ao longo do século XIX, um papel importante de significação do Oriente aos olhos dos europeus - e, por certo, o corpo feminino ocupou um lugar singular nesse processo. Como mostrou Said (Ibidem), escritores como Théophile Gautier, Gérard de Nerval e Gustave Flaubert fizeram das figuras femininas lendárias e sugestivas de Cleópatra, Salomé e Ísis um dos epítetos do Oriente no Ocidente. Porém, como evidenciou Lynne Thorton (1994, p. 20), foram os artistas visuais do século XIX, a exemplo de Jean-August Ingres e Jean-Léon Gérôme, que fizeram das mulheres "O mais popular de todos os temas da pintura orientalista", estabelecendo uma representação e significação do Oriente por meio de sua direta relação à figura feminina.

Assim, o discurso orientalista, para além de suas claras bases raciais, se sustentou (e ainda se sustenta) pelo que podemos chamar de feminiz̧ação do Oriente, um processo de generificação do Oriente que se estabelece, em muito, por meio de arquétipos femininos. Um exemplo disso pode ser visto pela recorrência da imagem da odalisca e da mulher com véu como expressão mesma do próprio Oriente - inclusive até hoje, como facilmente podemos ver nas imagens 
cotidianamente difundidas na mídia impressa e televisiva em geral. Com isso, cria-se uma equivalência incontornável na qual "a mulher é o Oriente, o Oriente é a mulher" - uma equivalência que tem como consequência seu imediato oposto: "posiciona o sujeito ocidental/ orientalista como masculino" (YEGENOGLU, 1998, p. 56).

Tais elementos se tornam importantes a nossos argumentos uma vez que entendemos, assim, as bases pelas quais a crítica feminista tem problematizado as formas como o discurso (neo)colonial tem se utilizado de uma espécie de engendramento do orientalismo: de um lado, como crítica aos modos como o gênero instituiu o discurso orientalista baseado na ideia de um Oriente/feminino a ser tutelado por um Ocidente/masculino (Ibidem), e, de outro, como crítica às formas como o discurso orientalista institui gênero por meio, especialmente, do modo como as mulheres orientais são representadas como vítimas de uma cultura bárbara (KHALID, 2011).

Neste sentido, o gênero do e no orientalismo sustenta (e se sustenta a partir de) uma estrutura binária de pensamento que vincula o masculino à cultura (logo, um Ocidente civilizado) e o feminino à natureza (logo, um Oriente exótico e bárbaro), em uma movimento de manutenção de redes de saber-poder que visam assegurar a estrutura de dominação (neo)colonial. Diante disso, perguntamos: como a arte de Morimura coloca em xeque essa feminização do Oriente - e isso sem necessariamente valer-se direta e linearmente da crítica feminista, mas de problematizações que podem, com ela, ser compartilhadas? $\mathrm{E}$, mais especialmente, como suas obras (re)inscrevem o feminino de forma afastada dos lugares que o discurso orientalista lhe reservou?

Diante da imagem de Morimura, somos concernidos por, pelo menos, duas questões: pela sobrevivência do corpo nu de Olympia, cujos sentidos sedimentares que causaram escândalo ao público do salão de Paris ainda se fazem presentes em Futago como uma espécie de murmúrio anacrônico; mas também pela conjugação desse corpo a um corpo concebido culturalmente como masculino e asiático. Ou seja, Olympia-Morimura desassossega nosso olhar ao fazer-se irredutível à reconhecibilidade dos marcos normativos binários dos quais somos sujeitos: o corpo que vemos na imagem não habita a lógica polarizada do masculino ou feminino, ocidental ou oriental, mas, distante das distinções binárias do ou, Olympia-Morimura conjuga, em seu corpo, possibilidades subjetivas de um $e$, um corpo feminino e masculino, oriental e ocidental. Há, então, na imagem, um borramento das fronteiras que separam de forma tão marcada as narrativas hegemônicas (e polarizadas) das diferenças humanas. 
Dessa conjugação de um $e$, as imagens se alinham aos feminismos não como movimento social, mas como uma crítica discursiva radical com efeitos decisórios na transformação e, por que não dizer, diluição das relações de poder em nossa cultura.

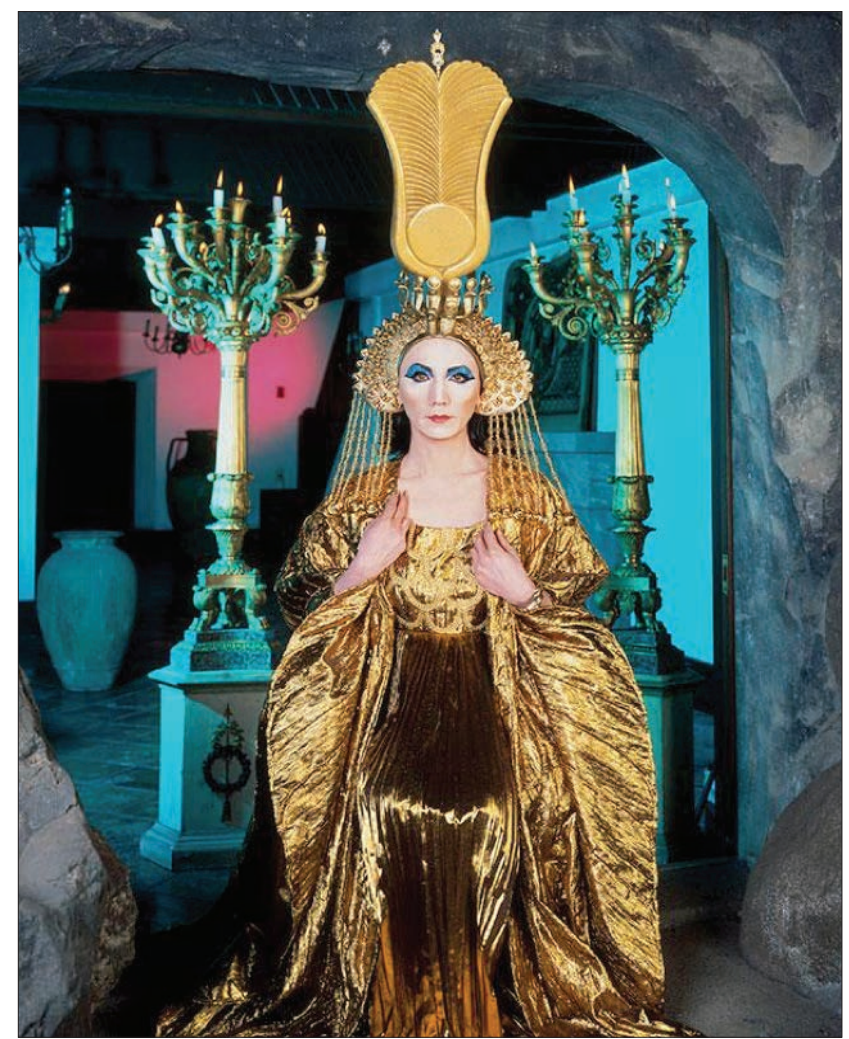

IMAGEM 4. After Elizabeth Taylor 1 de Yasumasa Morimura (1996).

Ilfochrome sob plexiglass, $120 \times 94.6 \mathrm{~cm}$.

Coleção particular.

Fonte: http://exhibitions.warhol.org/morimura/portfolio/self-portrait-actress-elizabeth-taylor-1-1996/

$\mathrm{O}$ autorretrato After Elizabeth Taylor 1 (Imagem 4) - produzido em 1996, como parte da série Actor/Actresses, realizada ao longo dos anos 1990 e composta por releituras de memoráveis personagens da história do cinema interpretadas por atrizes de Hollywood - partilha, em certa medida, desta crítica às estruturas binárias do discurso (neo) colonial. Em uma releitura da personagem Cleópatra, vivida por Elizabeth Taylor no filme de Joseph Mankiewic, de 1963, a imagem de Morimura se insere no seio de um intenso debate sobre as formas como a rainha Cleópatra incorpora, literalmente, os signos que a cultura ocidental reservou ao Oriente (SHOHAT, 2003). No autorretrato, 
temos uma Cleópatra trajando um vestido em lamê dourado, com as mãos prostradas sobre os adornos dos cabelos e uma coroa inspirada na representação de rainhas do Egito faraônico - referências tomadas de empréstimo da suntuosa cena em que a Cleópatra de Elizabeth Taylor chega a Roma para encontrar Júlio César (Imagem 5).

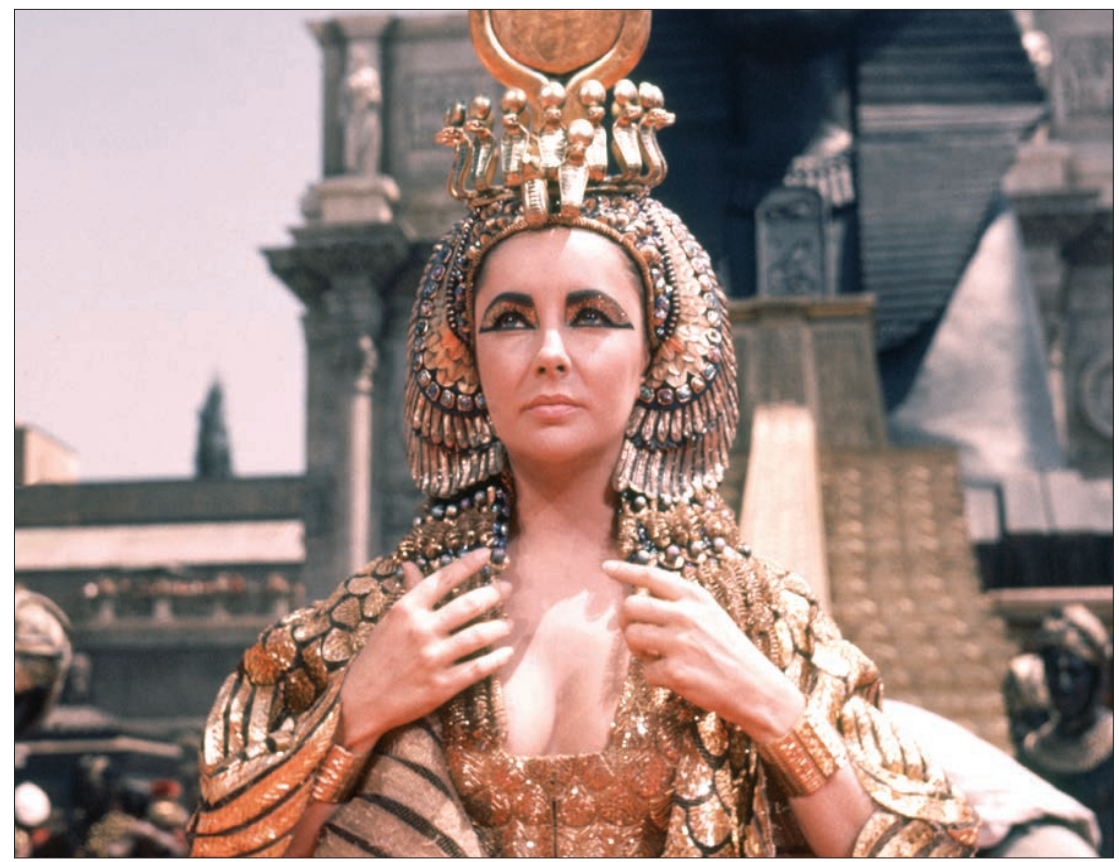

IMAGEM 5. Cleopatra de Joseph L. Mankiewicz (1963)

Filme, 35mm, colorido, $248 \mathrm{~min}$

Fonte: Twentieth Century Fox - EUA, RU e Suiça

Diante de Cleópatra estamos diante do Oriente. Em suas formas mais cristalizadas, as imagens modernas de Cleópatra incorporaram um conjunto discursivo que relegou o Oriente a uma ideia de feminino: a femme fatale, um arquétipo da modernidade que, ao ganhar força em meados do século XIX, construiu a noção de uma "feminilidade perigosa, naturalmente destinada à crueldade e à mentira, cuja beleza e sexualidade desenfreada podiam levar o homem à ruína física e moral" (MARTINS, 2001, p. 163). As relações amorosas de Cleópatra com os generais Júlio César e Marco Antônio são, de algum modo, sintomáticas dessa questão. $\mathrm{O}$ mundo moderno trouxe, na arte, no cinema, no teatro, no balé, etc., uma Cleópatra que fez de seu corpo o meio pelo qual exerceu uma política que ameaçou o mundo Ocidental, no ato mesmo em que subjugou, por meio da 
dissimulação e do sexo, dois dos maiores líderes da história romana, sendo, inclusive, representada como o motivo principal que levou César e, muito particularmente, Antônio à morte (BALTHAZAR, 2014; 2017). De Boccacio a David Coimbra, de Delacroix a Júlio Bressane - as mais recentes marcadas, de modo decisivo, pela interpretação de Elizabeth Taylor -, as imagens modernas de Cleópatra são artífices das formas como o gênero, como uma matriz binária de pensamento, dá sentido e significado ao discurso (neo)colonial.

Situar tais questões nos parece imprescindível para mostrar como, do mesmo modo que em Futago, a Cleópatra-Morimura nos causa estranhamento justamente por não ocupar um lugar claro tal como aquele sugerido pelas polaridades tradicionais de gênero, insinuando, ao invés disso, que a travessia entre elas, sua reversibilidade, se efetiva aqui como uma exigência ao olhar. Não podemos nomear o corpo de Cleópatra-Morimura, já que, na imagem, ele é um corpo dissidente, um corpo subversão. Cleópatra-Morimura é, talvez, o deslimite do gênero, pois, no ato de criação artístico irredutível à lógica do reconhecimento, assume a inconstância, a mutabilidade do gênero, provocando-nos a pensar para além dos limites culturalmente fixados e pensáveis de uma ontologia de gênero. Ao fazer isso, entendemos que a imagem sugere mais do que mera e prosaica ironia, já que, ao colocar em questão a ideia de que o corpo sexuado é nosso irrefutável destino, ela nos dá a ver como as verdades das quais somos sujeitos são ficções discursivas que habitam os corpos (BUTLER, 2002).

A partir destas considerações acerca dos modos como as imagens de Morimura tensionam o discurso normativo de uma cultura política de gênero, outro ponto que emerge nas duas obras ora analisadas diz respeito ao lugar do sujeito dos feminismos, especialmente nas dimensões em que as imagens se aproximam e se distanciam dos binarismos tão caros aos discursos de dominação. Ao longo da história dos feminismos, uma conjugação quase inquestionável entre as práticas feministas e o ser mulher se fez presente; por meio dela, por muito tempo, sustentou-se (e ainda se sustenta) a ideia de um sujeito coerente dos feminismos. Referimo-nos à ideia segundo a qual as mulheres e sua vitimização à estrutura sexista da sociedade são, dentro da lógica dos feminismos como política da identidade, uma produção discursiva de coalizão em uma política representacional identitária (BUTLER, 2008; MARIANO, 2005).

Se importa, para nós, pensarmos no sujeito dos feminismos, é porque entendemos que ele foi, durante muito tempo (e ainda o é para algumas correntes da crítica feminista), o catalisador das possibilidades de resistência e de lutas contra o machismo estrutural 
de nossa cultura. Assim colocado, a organicidade das formas de resistência sustentadas pela identidade mulheres como ponto de partida reivindicatório não rompe com as estruturas do discurso sexista e heteronormativo, mas, antes, pode-se dizer que "a categoria 'mulheres', o sujeito do feminismo, é produzida e reprimida pelas mesmas estruturas de poder por intermédio das quais busca-se a emancipação" (BUTLER, 2008, p. 14).

Como desdobramento, o sujeito dos feminismos sustenta entraves, muitas vezes, involuntários para uma prática feminista identitária, especialmente aqueles derivados da exclusão de todas as experiências de gênero que simplesmente não compartilham das possibilidades subjetivas promulgadas pela identidade mulheres. Para Judith Butler (2008, p. 22), os domínios de exclusão são reveladores das "consequências coercitivas e regulatórias dessa construção [o sujeito dos feminismos], mesmo quando a construção é elaborada com propósitos emancipatórios". Para exemplificar os limites do sujeito dos feminismos, lembramos aqui o recente caso da escritora Chimamanda Ngozi Adichie, cujo depoimento gerou fortes debates sobre a noção do sujeito do feminismo:

Eu penso que o problema de gênero no mundo é sobre experiências. Não é sobre como nós usamos nosso cabelo ou se temos uma vagina ou um pênis. É sobre o modo como o mundo nos trata. Acredito que se você viveu no mundo como um homem, com privilégios que o mundo reserva aos homens e, então, resolve trocar de gênero, é difícil, para mim, aceitar que sua experiência se equivale à experiência de uma mulher que viveu desde o início como uma mulher, a quem não foram concedidos os privilégios que os homens têm (ADICHIE, 2006, s.p.). ${ }^{6}$

Mesmo pensando o gênero como um fenômeno discursivo, a fala da autora nigeriana delineia que, no limite, a experiência de mulheres e homens é aquilo que a cultura inscreve sobre o corpo biológico, não sendo, então, possível "falar que as questões das mulheres são as mesmas que das mulheres trans" (Ibidem). Trazemos esse debate para tentar elucidar como a ideia de sujeito dos feminismos ainda reverbera inclusive dentro dos discursos que podemos qualificar como construcionistas, marcando o corpo como o lugar inegável do que somos e do que podemos ser. Mais do que isso, situar tal debate torna-se fundamental para entendermos os tensionamentos sugeridos na obra de Morimura a esse discurso fundacionista dos feminismos - mesmo que ele pulse, como uma espécie de murmúrio, nas correntes construcionistas.

De imediato, no caso das duas imagens que trazemos para análise, entendemos que se trata de clivagens que afrontam diferentemente uma aparente unidade do sujeito dos feminismos, 
qual seja, aquela relativa à interseccionalidade de raça e gênero. No caso de Futago, a serva de Olympia, Laura, prostrada atrás do seu leito, nos mostra o artista japonês em uma espécie de black face, em um tensionamento das intersecções do discurso racial com o discurso da diferença sexual, agindo, de algum modo, como "um duplo retorno dos reprimidos", conforme observou Norman Bryson (1996, p. 179) acerca de Futago. Como um corpo, ao mesmo tempo, negro e asiático, Laura-Morimura marca o lugar de outridade dessas duas experiências em nossa cultura, em sua subalternização a outras experiências igualmente marginalizadas: a da mulher branca e a da cortesã. Do encontro desses muitos outros (mulher, negra, asiática, branca, cortesã), emerge uma contribuição singular da imagem para pensarmos as marcas colonizadoras de nossa cultura, mas, singularmente, dos próprios feminismos, neste caso, por meio de relações de poder que se impõem entre as mulheres.

Ao falar sobre as tensões entre mulheres brancas e negras nos feminismos, beel hooks (2013, p. 138) afirma que, "embora o apelo à irmandade feminina seja frequentemente motivado por um desejo sincero de transformação do presente, não há a tentativa de assimilar a história ou as barreiras que podem tornar essa vinculação difícil, quase impossível". Ora, o que autora nos mostra é que a sororidade, enquanto espaço de solidariedade feminista, depende da compreensão das formas como o discurso racial (e, acrescentamos, no caso da análise em questão, étnico) estruturou relações de poder, por vezes verticalizadas, entre as próprias mulheres. Para beel hooks, é preciso enfrentar as feridas históricas deixadas pela relação de serva-senhora - tal qual aquelas que vemos retificada, por exemplo, na própria pintura de Manet.

Em contrapartida, Futago borra as relações de centro e margem no momento em que o corpo de Morimura se funde com o de Olympia e de Laura: se as duas figuras na imagem são personagens diferentes em termos raciais, étnicos e de classe, ali compartilham o mesmo corpo masculino em um ato de performatização do feminino. Morimuma é, pois, um e muitos, e todos, ao mesmo tempo. A junção das subjetividades marginais na mesma imagem de um corpo, em uma imagem que se apropria de uma pintura canônica da arte do Ocidente, desloca o caráter abjeto próprio dessas múltiplas subjetividades por meio do borramento irônico e paródico das fronteiras de gênero.

De modo semelhante, em After Elizabeth Taylor, a mesma questão de pensar o lugar do sujeito dos feminismos por meio de clivagens relativas ao cruzamento entre raça e gênero se efetiva como elemento decisivo. Aqui, esse debate emerge a partir da disputa pelo pertencimento cultural de Cleópatra: 
[...] investimentos científicos [no caso, os debates produzidos no interior dos estudos egiptológicos e clássicos] e artísticos sugerem, numa particular visualidade para Cleópatra, que sua figura se transformou em um campo metafórico para as batalhas raciais contemporâneas, especialmente no Ocidente pós-colonial (SHOHAT, 2003, p. 127).

O engendramento do racismo permite a Ella Shohat mostrar como a mítica beleza da última monarca do antigo Vale do Nilo, por exemplo, só pode ser retratada, no cinema hollywoodiano, por atrizes brancas como se a beleza lendária de Cleópatra, que, como já referido, colocou líderes icônicos do Ocidente sob seu poder, simplesmente não pudesse ser incorporada por um corpo negro. Aqui, então, estabelece-se uma relação de imbricação da crítica feminista ao discurso (neo)colonial Cleópatra foi reclamada como um "ícone moderno do feminismo" (ASHTON, 2008, p. 8) por ser uma figura simbólica de ideias caras à crítica feminista: a liberdade sexual e a ação legítima das mulheres na política. Contudo, essa ressignificação da imagem da rainha é inseparável da manutenção da representação de uma mulher branca, uma imagem facilitada por uma questão histórica específica: na ascendência grecomacedônica de sua casa dinástica, na adoção do costume faraônico da endogamia e no ato de fazer de Alexandria (à época, capital egípcia) o último elo do mundo antigo com a cultura helênica, Cleópatra e sua linhagem dinástica passaram a ser representadas, seja na historiografia, seja em artefatos culturais modernos, como grega, o que é, em vários sentidos, tomado como sinônimo de uma pele caucasiana (ASHTON, 2003; BALTHAZAR, 2017; SHOHAT, 2003).

No entanto, o feminismo alinhado ao movimento negro tem reclamado Cleópatra como uma governante de um país localizado no norte da África, em um movimento sintomático das clivagens produzidas por mulheres negras no seio de correntes feministas marcadamente constituídas por mulheres brancas. Assim, estudiosas têm colocado em rasura a ideia de uma ascendência puramente greco-macedônica, especialmente nos debates sobre traços genéticos africanos nos restos mortais de corpos identificados como os da avó - uma concubina de Ptolomeu XI - de Cleópatra (SHOHAT, 2003). Frente a essas proposições, a ideia de uma Cleópatra negra se tornou uma controvérsia na academia, uma espécie de "peão no argumento advogado por afrocentristas que vêm Cleópatra como a representante principal da antiga África negra" (WALKER \& ASHTON, 2003, p. 14).

Importa, deste debate, pensar como os próprios feminismos sustentam as disputas sobre o pertencimento cultural da última rainha do Egito, como se ele pudesse ser resumido à definição de uma origem (europeia ou africana). Como, então, a imagem de Morimura 
nos provoca a tensionar as disputas de ordem binária e, muitas vezes, essencialistas a que nos referimos? After Elizabeth Taylor traz uma incômoda desestabilização por seu caráter tríplice, tal como sugerido pela "camada de máscaras em que o artista se funde a uma atriz interpretando uma terceira pessoa" (SMITH, 1996, s.p). CleópatraMorimura inscreve um terceiro elemento: o corpo de um japonês, como um ponto que desestabiliza a ideia de um discurso eurocêntrico versus discurso afrocêntrico. Dessa rasura do versus, CleópatraMorimura emerge não como branca ou negra, mas como uma figura que reúne, em si, a cultura grega e a africana. Da mesma forma, talvez possamos sugerir pela presença do corpo do artista, emerge também uma questão muitas vezes esquecida nos debates polarizados: se Cleópatra era uma rainha de ascendência grega que governou um reino africano, ela foi governante de uma sociedade que pertenceu ao que chamamos de antigo oriente próximo. Logo, CleópatraMorimura sugere como as fronteiras aparentemente estáveis que separam Oriente e Ocidente não são terrenos tão distantes.

Sob essa última questão, é interessante pensarmos que, além das marcas do rosto e do corpo do artista, outras camadas de pistas da cultura japonesa se manifestam nos autorretratos de Morimura - como, por exemplo, "o vestido de Cleópatra, que lembra os vestidos plissados do inventivo designer de moda japonês Issey Miyake” (FRIIS-HASEN, 1997, p. 8). Na análise que faz sobre a mesma imagem, Dana Friis-Hansen (Ibidem) afirma que essa característica, em nada aleatória, produz um desconforto àquilo que parece ser, então, imediatamente reconhecido: "para os olhos ocidentais, o que inicialmente parecia uma personagem familiar de um filme massmedia se torna, dentro de uma leitura transnacional, uma mutante multicultural”. Assim, Cleópatra-Morimura não é a imagem de uma mulher completamente estadunidense, europeia, africana ou asiática, mas é a soma da profusão de contatos culturais, permitindonos entender que After Elizabeth Taylor se efetiva também como uma crítica às formas como as polaridades da ordem do discurso de gênero estruturam algumas formas de resistência.

A oposição das mulheres negras a um feminismo que afirmava lhes representar tem sido amplamente discutida e, mesmo que não totalmente resolvida, operou um movimento importante de tensionamento à ideia de um sujeito dos feminismos, bem como das pautas de luta que dizem respeito a esse sujeito universal. Mesmo com as muitas clivagens promovidas por mulheres negras, os feminismos ainda olham para o Oriente, e para os países asiáticos de modo singular, como um lugar em que as mulheres sofrem com um machismo 
quase primitivo, incivilizado por não ser ocidental. Joan Scott (2010) analisou, por exemplo, como os feminismos franceses apoiaram de diferentes formas uma lei que proibia o uso de hijab em lugares públicos, como as escolas. Diz a autora: "a razão [para a aprovação da lei] dada por políticos e por muitas feministas foi a mesma: o véu representava a subordinação das mulheres, sua humilhação e sua desigualdade" (Ibidem, p. 155). Em sua análise, a autora reconheceu como as feministas francesas buscaram prover às novas gerações de mulheres árabes instrumentos para sua emancipação, sem levar em conta o caráter eurocêntrico de sua postura frente ao uso do véu - como, por exemplo, a ignorância de que algumas feministas muçulmanas consideram o véu um símbolo de sua liberdade sexual.

Diante desse olhar eurocêntrico e vitimizador das mulheres asiáticas, a imagem de Cleópatra-Morimura nos constrange com uma afronta radical: a negação, nos países ocidentais, da construção de uma menorização das culturas da Ásia frente a um ocidente civilizado, tendo as mulheres não-asiáticas - sejam elas brancas ou negras, feministas ou não - um papel importante na construção dos matizes de dominação do discurso (neo)colonial (HASAN, 2012). Em outros termos, sugerimos, com a presente análise, como as imagens de Morimura colocam em xeque como algumas vertentes dos feminismos sustentaram uma perspectiva identitária universalizante: o sujeito mulher.

Nos termos Saba Mahmood (2005, p. 15), a construção de um sujeito homogêneo dos feminismos - mas que, historicamente, foi (e é) um fruto dos feminismos liberais, logo, marcadamente eurocêntrico - trouxe o risco de orientalizar, uma vez mais, as mulheres que vivem no que chamamos, hoje, de Oriente: "repetindo os erros da intelectualidade orientalista dos anos 1970, que definia as Mulheres do Oriente Médio como 'outra', passiva e submissa, despojadas da consciência iluminada das suas 'irmãs ocidentais' e, portanto, condenadas a vidas de submissão servil ao homem". Com efeito, e fazendo aqui uma análise em termos de uma leitura interseccional, as imagens de Morimura se aproximam de um feminismo que não busca o consenso das identidades universalizantes tão caras ao pensamento liberal, mas, antes, o dissenso tão necessário para o aprofundamento do conceito mesmo de democracia pluralista (MOUFFE, 1999). Tal análise se faz possível justamente na medida em que nos aproximamos à pressuposição pessoalmente assumida de Judith Butler (2015, s./p.), a quem o "feminismo está ligado ao compromisso com o movimento LGBT-queer, tanto aos seus direitos e às suas aspirações, mas também às políticas que se opõem ao racismo, à precariedade e, evidentemente, todo compromisso com a democracia de forma radical". 
Levando em conta os debates sobre o sujeito dos feminismos, voltemo-nos a um último elemento fundamental posto pelas obras do artista que se coloca como questão para pensarmos o lugar do sujeito: a forma como, não por acaso, Morimura escolhe assumir, performaticamente, o lugar ocupado por uma mulher. Nesse caso, entendemos que o debate sobre sujeito dos feminismos emerge das constantes personificações do feminino em um diálogo com a performance das drag queens (MORGAN, 2013). Na acepção do termo, conforme Guacira Louro (2009, p. 139), a drag queen incorpora o feminino, mas, ao fazer isso, denuncia o caráter cultural, fabricado, do gênero: "imitar um gênero pode ser uma forma de mostrar o caráter imitativo do gênero; mais do que isso, pode ser um modo de desnaturalizar a ligação entre o sexo e gênero que é, ordinariamente, tomada como natural". Por extensão, e seguindo ainda a leitura de Morgan - feita, igualmente, sobre a obra de Morimura -, entendemos que Futago e After Elizabeth Taylor podem, na esteira das drags, ser concebidas como imagens paródicas do feminino.

No entanto, também aqui há uma imbricação de sentidos, na qual a uma espécie de performance drag soma-se a algo marcadamente japonês: Dana Friis-Hansen (1997) afirma que Morimura, ao se colocar como mulher em suas imagens, se apropriou de uma antiga tradição artística do Japão - o teatro Kabuki. Nele, atores conhecidos como onnagata se especializaram em interpretar personagens mulheres - e isso por uma questão histórica, já que, em 1629, as mulheres foram proibidas de entrar nos quarteirões de entretenimento devido aos altos índices de prostituição (nem como público, nem como atrizes). Semelhante às performances artísticas das drag queens: "ele [o onnogata] consegue estilizar a mulher perfeita, precisamente porque ele é um homem" (FRIISHANSEN, 1997, p. 4). Em outros termos, a autora chama atenção, justamente, para como a mulherperfeita - um corpo totalmente coerente às normas de gênero - só é possível no ato de um corpo masculino performatizando o feminino. Segundo Guacira Louro (2004), nunca estamos plenamente enquadrados às normas de gênero. A perfeição de um sujeito de gênero é, portanto, algo impossível, sendo exatamente isto que as drags, ao se montarem como mulheres, denunciam: não há, nessa forma de performance, o desejo de ser uma mulher, mas é pelo exagero dos traços do feminino que a drag "efetivamente incorpora, que ela toma corpo, que ela se materializa e passa a existir" e, com isso, "subverte o sujeito que imita" (LOURO, 2004, p. 85).

Ao trazermos esta discussão, queremos pontuar que, seja como drag, seja como onnogata, as obras de Morimura operam o gênero em 
seu caráter contingente, pois não são imagens de mulheres (ou de um homem) brancas, negras ou asiáticas. Antes disso, trata-se de corpos que, na própria intersecção dos marcadores sociais que dão lugar, mostram a radicalidade de suas construções culturais, subvertendo, assim, a aparente fixidez das subjetividades das quais se apropria. Neste sentido, e dando continuidade a nossos argumentos, acreditamos que Futago e After Elizabeth Taylor se inscrevem em um certo movimento crítico igualmente presente e enfático nos feminismos: aquele que busca de forma radical a dissidência, capaz de questionar, a um só tempo, os modos como o gênero, enquanto matriz binária de pensamento, afirma as verdades que buscam normalizar os corpos.

Não estamos defendendooabandono dacategoria mulheres, mas, na esteira de Judith Butler, consideramos importante problematizar como o termo evidencia disputas sobre as possibilidades subjetivas de nosso tempo. Acreditamos que, assim procedendo, poderemos "liberar o termo num futuro de múltiplas significações, emancipá-lo das ontologias maternais ou racistas às quais esteve restrito e fazer dele um lugar onde significados não antecipados podem emergir" (BUTLER, 1998, p. 36).

Ao nos provocar a nos reinscrevermos diferentemente nas relações que estabelecemos com as verdades hegemônicas, entendemos, como buscamos demonstrar, que as imagens de Morimura nos convidam, de múltiplas formas, a partilhar do êthos feminista, sugerindo sujeitos fronteiriços, subjetividades, talvez, irreconhecíveis e irredutíveis aos marcos binários que sustentam uma determinada ontologia do sujeito. Se o preço a pagar para partilhardo êthos crítico feminista é a não reconhecibilidade como sujeitos, a pergunta que as imagens de Morimura nos colocam é urgente, incômoda e, talvez, intransponível: se é certo que é preciso transformar o nosso pensamento, o que podemos suportar pensar?

\section{CONSIDERACฺ̃̃ES FINAIS}

Buscamos, no presente texto, tecer algumas considerações sobre as possibilidades de pensar os feminismos como uma expressão do que poderíamos chamar, a partir das discussões de Judith Butler e Michel Foucault, de uma atitude crítica aos modos como nos tornamos sujeitos na cultura. Em uma aproximação mais imediata, remontamos ao conceito de crítica para, então, delinear uma relação possível do sujeito com a verdade de modo afastado da ordem da sujeição e de uma política da verdade capaz de cingir, constranger, limitar, as 
possibilidades subjetivas. Assim, entendemos que a crítica emerge como possibilidade de mudança de pensamento, em um processo interrogativo no qual há conflitos, afrontamentos, lutas, resistências, em uma espécie de "reativação de uma atitude; ou seja, um êthos filosófico que seria possível caracterizar como crítica permanente de nosso ser histórico" (FOUCAULT, 2013c, p. 361).

No curso da longa história da constituição de um êthos crítico feminista, houve múltiplos caminhos trilhados para a proposição de ações, de práticas, de modos de ser feministas. Sabemos que, claro, essa acepção não é, de modo algum, homogênea ou de entendimento fácil e aceito irrestritamente. Para Ana Paula Martins (2016), as motivações os caminhos que levaram muitas mulheres e mesmo homens a simpatizarem com esse movimento ou mesmo a aderir a ele são plurais e, por vezes, contraditórias, mas, em seu conjunto, estão comprometidas com a superação das limitações e das injustiças que marcaram (e marcam) profundamente as relações de gênero. Importa, portanto, dizer que a filosofia foi, como tentamos mostrar, um caminho possível ao êthos crítico feminista, mas, certamente, não o único. Como exemplo, lembramos, a partir do estudo de Ana Paula Martins (Ibidem), como a religião foi uma outra vereda pouco associada aos feminismos, pois - apesar de concebida, por um longo tempo, como inconciliável à militância política feminista stricto sensu - os movimentos de caridade cristã possibilitaram com que várias mulheres se envolvessem com questões fundamentais para a edificação do que poderíamos também nomear de um êthos crítico feminista (como, por exemplo, o movimento abolicionista, a construção de espaços educacionais de meninas e a luta por melhores condições para as mulheres das classes trabalhadoras). Outro caminho possível um possível êthos crítico feminista poderia ser vinculado às produções culturais alinhadas ao pensamento feminista voltadas, por exemplo, à escrita literária. Nesse âmbito, Norma Telles (2007, p. 15) mostrou como a literatura escrita por mulheres não privilegia apenas a denúncia de uma sociedade injusta em termos de gênero, mas, talvez como crítica mais expressiva, se constituiu como um elemento cultural decisivo para o "rompimento do sistema de representação dominante" fundamentalmente masculino.

Sob estes pressupostos, destacamos, entre as muitas veredas possíveis, as artes visuais como um possível caminho capaz de sugerir, em termos de uma filosofia, uma transformação do pensamento por meio de uma atitude feminista, um modo de estar, diante do mundo. Para tanto, analisamos dois autorretratos de Yasumasa Morimura a partir de dois movimentos centrais que, em seu conjunto, tensionam 
as relações que tecemos com as verdades hegemônicas do nosso tempo: primeiramente, problematizamos os modos como a arte de Morimura borra os modos como o discurso (neo)colonial se estrutura (e é estruturado) por concepções binárias de gênero, pensando em como os autorretratos nos convocam a habitar as incertezas das fronteiras (de gênero, raça e etnia). Em seguida, analisamos os modos pelos quais as imagens de Morimura colocam sob rasura a categoria mulheres, sobretudo quando assumida pelos feminismos como política identitária. Entendemos, assim, que as imagens nos sugerem a possibilidade de pensar em modos de viver gênero e sexualidade distantes das marcas binárias que estruturam os discursos de dominação e de resistência. Mais do que isso, os autorretratos de Yasumasa Morimura se aproximam do êthos feminista ao formular uma crítica capaz de promover renovações nos próprios feminismos, reinscrevendo-os, para além dos termos da militância política, como uma forma de pensamento capaz de nos transformar em sujeitos irredutíveis às formas instituídas de viver os corpos.

\section{REFERÊNCIAS BIBLIOGRÁFICAS}

ASHTON, S.-A. The last queens of Egypt. London: Pearson Longman, 2003.

ASHTON, S.-A. Cleopatra and Egypt. London: Blackwell Publishing, 2008.

BALThAZAR, G. O Gênero do Poder: Plutarco e a contenda de Otávio e Cleópatra. In: CANDIDO, M. R.; CAMPOS, C. E. (org.). Caesar Augustus: entre práticas e representações. Vitória/Rio de Janeiro: DLL/UFES; NEA/UERJ, p. 215-238, 2014.

BALTHAZAR, G. Um corpo sobrevivente: as tênues fronteiras de gênero nas imagens sobre Cleópatra do final do século XIX. Anais do 13 Women's World \& Simpósio Internacional Fazendo Gênero 10. Florianópolis: UFSC, 30/07-04/08, 2017. p. 1-12. Disponível em: <https://goo.gl/8PaZdb>. Acesso em: 12 mar. 2017.

BENHABIB, S.; CORNELL, D. (ed.). Feminism as critique. Minneapolis: University of Minnesota Press, 1996.

BRYSON, N. Morimura's Olympia. In: GARBER, Marjorie et al. (ed.). Field work: sites in literary and cultural studies. New York and London: Routledge, p.175-182, 1996.

BUTLER, J. Fundamentos contingentes: o feminismo e a questão do "pós-modernismo". Cadernos Pagu, n. 11, p. 11-42, 1998. Disponível em: <https://goo.gl/07c54Q>. Acesso em: 13 mai. 2017.

BUTLER, J. Giving an account of oneself. New York: Fordham University Press, 2005.

BUTLER, J. Problemas de gênero. Rio de Janeiro: Civilização Brasileira, 2008. 
BUTLER, J. Queremos continuar vivendo e amando fora de zonas jurídicas e legais: entrevista à Mariana Carbajal. IHU Online, Set., 2015. Disponível em: <https://goo.gl/ nm8Xdf>. Acesso em: 20 mai. 2018.

BUTLER, J. Critique, dissent, disciplinary. Critical Inquary, v. 35, n. 4, p. 773-797, 2009. Disponível em: <https://goo.gl/eP4iAx>. Acesso em: 02 mai. 2018.

BUTLER, J. O que é a crítica? um ensaio sobre a virtude de Foucault. Cadernos de Ética e Filosofia Política, n. 22, p.159-178, 2013. Disponível em: <https://goo.gl/9fIQs9>. Acesso em: 13 mai. 2017.

CLARCK, T. J. A pintura da vida moderna. São Paulo: Cia. das Letras, 2004.

FELSKI, R. Doing time: feminist theory and postmodern culture. New York: New York University Press, 1999.

FISCHER, R. Docência, cinema e televisão: questões sobre formação ética e estética. Revista Brasileira de Educação, v. 14, n. 40, p. 93-102, 2009. Disponível em: <https:// goo.gl/yrN6kh>. Acesso em: 02 mai. 2018.

FOUCAULT, M. Herculine Barbin: o diário de um hermafrodita. Rio de Janeiro: Francisco Alves, 1982.

FOUCAULT, M. História da sexualidade II: o uso dos prazeres. Rio de Janeiro: Edições Graal, 1984.

FOUCAULT, M. What is critique? In: FOUCAULT, M. The politics of truth. New York: Semiotext(e), 1997.

FOUCAUlT, M. A ordem do discurso. São Paulo: Edições Loyola, 2009.

FOUCAULT, M. O sujeito e o poder. In: DREYFUS, Hubert \& RABINOW, Paul. Michel Foucault. Rio de Janeiro: Fowrense Universitária, p. 273-295, 2010a.

FOUCAULT, M. Michel Foucault entrevistado por Hubert Dreyfus e Paul Rabinow. In: DREYFUS, Hubert \& RABINOW, Paul. Michel Foucault. Rio de Janeiro: Forense Universitária, p. 296-342, 2010b.

FOUCAULT, M. Estruturalismo e pós-estruturalismo. In: FOUCAULT, M. Ditos \& escritos II: arqueologia das ciências humanas e história dos sistemas de pensamento. Rio de Janeiro: Forense Universitária, p. 322-350, 2013a.

FOUCAULT, M. É importante pensar? In: FOUCAULT, M. Ditos \& escritos IV: repensar a política. Rio de Janeiro: Forense Universitária, p. 354-358, 2013b.

FOUCAULT, M. O que são as luzes? In: FOUCAULT, M Ditos \& escritos II: arqueologia das ciências humanas e história dos sistemas de pensamento. Rio de Janeiro: Forense Universitária, p. 351-368, 2013c.

FOUCAULT, M. Aulas sobre a vontade de saber. São Paulo: Martins Fontes, 2014a.

FOUCAULT, M. Michel Foucault, uma entrevista: sexo, poder e política da identidade. In: FOUCAULT, M. Ditos \& escritos IX: genealogia da ética, subjetividade e sexualidade. Rio de Janeiro: Forense Universitária, p.251-263, 2014b. 
FRIIS-HANSEN, D. Yasumasa Morimura: actor/actresses. Houston: Contemporary Art Museum, 1997.

HASAN, M. Feminism as Islamophobia: a review of misogyny charges against Islam. Intellectual Discourse, n. 20, v. 1, p. 55-78, 2012. Disponível em: <https://goo.gl/ WLEpPG>. Acesso em: 13 mai. 2017.

KHALID, M. Gender, orientalism and representations of the 'other' in the war on terror. Global Change, n. 23, v. 1, p.15-29, 2011. Disponível em: <https://goo.gl/tdFsfn>. Acesso em: 13 mai. 2017.

KHAN, D. Questions of cultural identity and difference in the work of Yasumasa Morimura, Mariko Mori and Takashi Murakami. Canterbury. Master's thesis, Art History, University of Canterbury, 2007.

hooks, bell. Ensinar a transgredir: a educação como prática da liberdade. São Paulo: Martins Fontes, 2013.

LOURO, G. L. Corpos estranhos: ensaios sobre a sexualidade e a teoria queer. Belo Horizonte: Autêntica, 2004.

LOURO, G. L. Foucault e os estudos queer. In: RAGO, M. \& VEIGA-NETO, A. (org.). Por uma vida não-fascista. Belo Horizonte: Autêntica, p.135-199, 2009.

$M A H M O O D, S$. Politics of piety: the Islamic revival and the feminist subject. Princeton: Princeton University Press, 2005.

MARIANO, S. O sujeito do feminismo e o pós-estruturalismo. Revista de Estudos Feministas, v. 13, n. 3, pp. 483-505, 2005. Disponível em: < https://goo.gl/K9XAPA>. Acesso em: 13 mai. 2017.

MARTINS, A. P. Caminhos para o feminismo: das relações entre o movimento pelos direitos das mulheres, o humanismo liberal, a religião e a filantropia no século XIX. In: KLANOVICZ, L. et al. (org.). Estudos de gênero em perspectiva. Ponta Grossa: ANPUH, p.9-43, 2016.

MARTINS, A. P. O caso Naná: representações de gênero no encontro entre texto e imagem no século XIX. História: questões \& debates, v. 34, n. 1, p. 157-174, 2001. Disponível em: <https://goo.gl/k5lsiy>. Acesso em: 13 mai. 2017.

MEYER, Dagmar. Gênero e educação: teoria e política. In: LOURO, Guacira et al. (org.). Corpo, gênero e sexualidade. Petrópolis, Vozes, p. 9-27, 2003.

MORGAN, R. Yasumasa Morimura's kingdom of art. In: MORIMURA, Y. Theater of the Self. Pittsburg, The Andy Warhol Museum, p.35-49, 2013.

MORIMURA, Y. A change in gender for new political series: Kay Ioti interview with Yasumasa Morimura. The Japan Time, oct. 2006. Disponível em: <https://goo. gl/0CDSSw>. Acesso em: 13 mai. 2017.

MOUFFE, C. Feminismo, cidadania e política democrática radical. Debate Feminista. Cidadania e Feminismo (Edição especial). São Paulo: Cia. Melhoramentos, p. 29-47, 1999. 
POLLOCK, G. Differencing the canon: feminist desire and the writing of art's histories. London \& New York: Routlegde, 2003.

RAGO, M. Feminizar é preciso: por uma cultura filógina. Revista da Fundação Sead, v. 15, n. 3, p. 58-66, 2001. Disponível em: <https://goo.gl/ZvUQDD>. Acesso em: 13 mai. 2017.

RAGO, M. Feminismo e subjetividade em tempos pós-modernos. In: COSTA, Claudia Lima et al. (org.). Poéticas e políticas feministas. Florianópolis: Editora das Mulheres, p. 31-41, 2004.

SAID, E. Orientalismo: o oriente como invenção do ocidente. São Paulo: Cia. das Letras, 2007.

SCOTT, J. The politics of the veil. Princeton: Princeton University Press, 2010.

SHOHAT, E. Disorienting Cleopatra: a modern trope of identity. In: WALKER, Susan \& ASHTON, Sally-Ann (ed.). Cleopatra reassessed. London: British Museum Press, p.127138, 2003.

SMITH, R. Seeing 3 images in one face. The New York Times, Dec. 6th, 1996. Disponível em: <https://goo.gl/TPqtXC>. Acesso em: 13 mai. 2017.

SPIVAK, G. Feminism and critical theory. In: LANDRY, D. The Spivak reader. London: Routledge, p. 53-74, 1996.

TELLES, N. Belas e feras. São Paulo: NatEditorial, 2007.

THORTON, L. Women as portrayed in orientalist painting. Paris: ACR Édition Internationale, 1994.

WALKER, S. \& ASHTON, S.-A. Cleopatra. London: Bristol Classical Press, 2006.

YEGENOGLU, M. Colonial fantasies: towards a feminist reading or orientalism. Cambridge: Cambridge University Press, 1998.

\section{NOTAS}

${ }^{1}$ Agradecemos, de modo especial, à amiga e colega Raquel Leão Luz por gentilmente nos ceder a imagem para compor este texto.

${ }^{2}$ A primavera das mulheres se refere aos protestos que reuniram, ao final de 2015, milhares de mulheres nas ruas de diferentes cidades brasileiras contra, especialmente, o projeto de Lei 5069, que previa a retirada de direitos à assistência multidisciplinar às vítimas de violência sexual (sobretudo aqueles que asseguram o aborto), então garantidos pela Lei 12.845, sancionada pelo governo Dilma Rousseff em 2013. Lembramos, ainda, que o termo "primavera das mulheres" foi, naquele momento, amplamente divulgado e reforçado pela mídia brasileira e mesmo internacional. Um exemplo disso pode ser visto em reportagens publicadas, no mesmo período, em jornais como o britânico The Guardian (In Braz̨il, women are fighting against the sexist impeachment of Dilma Rousseff, de 5 de julho de 2016; disponível em: https://goo.gl/CKocd9) e o estadunidense The New York. Times (Rousseff impeachment galvanizes Brazilian feminists from all sides of politics", de 5 de julho de 2016; disponível em: https://goo.gl/c5dJfE), em que, à época do impeachment de Dilma Rousseff, relembram a importante luta das mulheres, desde primavera das mulheres em 2015, pela manutenção da democracia e dos direitos humanos no Brasil. 
${ }^{3}$ Considerando que as apostas teórico-políticas da crítica feminista são, por certo, polissêmicas e, por vezes, conflitantes, é necessário, como colocou Judith Butler (2009, p. 775), "especificar a noção de crítica que consideramos valer a pena defender". Se marcamos nossa vinculação ao conceito de crítica proposto por Michel Foucault, é, pois, por nos alinharmos, na esteira de Butler, mas também de autoras como Guacira Louro (2004), Dagmar Meyer (2003) e Margareth Rago (2004), ao arcabouço teórico dos estudos feministas pós-estruturalistas que se apoiam, substancialmente, nos instrumentos conceituais foucaultianos. Acerca de outras vertentes interpretativas possíveis sobre a noção mesma de crítica nos e dos feminismos, ver os estudos de Gayatri Spivak (1996), Seyla Benhabib e Drucilla Cornell (1996) e Rita Feslki (2000).

${ }^{4}$ Como um exemplo desses gestos, trazemos uma cena narrada por Mahmood (2005) de quando acompanhou a conversa de duas mulheres pertencentes ao movimento pietista no Egito: Iman, uma mulher solteira na casa dos trinta anos, procurou conselhos de Nadia, uma mulher casada na mesma faixa etária de idade e professora de Alcorão na mesquita. Iman confessou à Nadia seu incômodo diante da proposta de casamento de um homem respeitado, mas com uma segunda esposa; Nadia, por sua vez, aconselhou Iman a pedir ao pretendente ir conversar com seus pais, no sentido de que pudessem investigar a vida do homem e, assim, aprovar ou não o matrimônio. Diante da resposta, Mahmood se sentiu incomodada e questionou à Nadia a razão de ter sugerido que Iman aceitasse a proposta de um homem já casado. Como resposta, Nadia falou de como a sociedade egípcia considera que as mulheres solteiras a partir dos vinte anos têm algum um defeito, pois, diferentemente dos homens solteiros - por escolha -, assume-se, no sentido da culpabilização, que ninguém quis aquela mulher. Para Mahmood, seu espanto diante da resposta de Nadia é uma marca da incapacidade do "pensamento político feminista para visualizar formas relevantes de crescimento humano fora dos limites do imaginário liberal” (Ibidem, p. 155). Mais centralmente, o caso de Nadia demonstrava, para Mahmood, como as mulheres inseridas e caudatárias de movimentos femininos conservadores possuem uma compreensão das possibilidades e limites subjetivos de suas culturas, tecendo, em relação a um tipo particular de resistência como subversão, possibilidades de existência, de sobrevivência, no seio mesmo da normatividade de gênero.

${ }^{5}$ Fazemos alusão à afirmação "no fundo do sexo, está a verdade", usada por Foucault (1982, p. 4) para mostrar que, com a emergência da ideia de um verdadeiro sexo, passamos a entendê-lo, nas sociedades modernas, com o lócus onde se aloja nossa verdade mais íntima, sendo nele que (se) esconderia o que há de mais "verdadeiro" em nós.

${ }^{6}$ Trazemos esse excerto de Chimamanda na medida em que ela tem se afirmado, no cenário internacional, como uma importante voz sobre temáticas que circundam as questões dos direitos humanos, como, por exemplo, trabalhando em romances como Americanah e Hibiscos Roxos, traduzidos para mais de trinta línguas, com diferentes problemáticas sobre a interseccionalidade das questões raciais com o gênero. No âmbito específico dos feminismos, Chimamanda produziu, até o momento, dois manifestos feministas: Sejamos todos feministas e Para educar uma criança feminista. Além disso, a autora se coloca como uma defensora dos direitos das chamadas minorias sociais e realiza trabalhos humanitários em diversos lugares do mundo, sobretudo na Nigéria e em outros países africanos, tendo, inclusive, recebido prêmios internacionais de literatura e direitos humanos. Ao apresentar suas ideias em uma linguagem mais acessível a um público mais amplo - como é o caso da literatura, de filmes (baseados em livros de sua autoria) ou até mesmo de inserções de s ${ }^{\circ}$ uas falas em clipes da música pop internacional (como o da cantora Beyoncé) -, Chimamanda tem sido tomada como uma importante referência sobre temáticas caras e urgentes de nosso tempo, sendo convocada, sobretudo pela grande mídia, a falar sobre a questão racial ou sobre gênero e 
feminismos. No caso da passagem que citamos no texto, referimo-nos a uma entrevista sobre feminismos concedida por Chimamanda à Cathy Newman e veiculada pela emissora britânica Chanel 4, na ocasião do recente lançamento do manifesto Para educar uma criança feminista. $\mathrm{Na}$ entrevista, Chimamanda fez uma controversa afirmativa sobre a experiência de gênero das mulheres trans, o que causou um debate internacional sobre a questão do lugar reservado às mulheres trans nos feminismos. A entrevista está disponível no site do Chanel 4 : https://www.channel4.com/news/chimamanda-ngozi-adichie-on-feminism.

Submetido: $13 / 03 / 2018$

Aprovado: 26/05/2018

Contato:

Gregory da Silva Balthazar

Rua Doutor Malheiros, 167, Bairro Santo Antônio.

Porto Alegre |RS|Brasil

CEP 90.640-050 